\title{
Specific aspects related to the partnership agreement*
}

\author{
Assistant Professor, PhD Andreea SEUCAN \\ Bucharest University of Economic Studies- Department of Law \\ andreea.seucan@cig.ase.ro
}

\begin{abstract}
The scientific paper covers specific aspects of the partnership agreement, according to the provisions of the New Civil Code. The paper explains why the partnership agreement is different from other contracts set forth in the New Civil Code. It focuses mainly on answering the question if the partnership agreement has a synallagmatic nature or not. In this sense, it explains the meaning of the classification in unilateral and bilateral (synallagmatic) contracts and it analyses the obligations of the parties of a partnership agreement in order to determine if they are reciprocal and interdependent or not.
\end{abstract}

Key words: partnership agreement, synallagmatic nature, special contract.

JEL Classification: K12

\section{Introduction}

One of the concepts covered by the New Civil Code is that of contracts set forth under Title IX "Different special contracts". We are not able to understand the reason behind the use of the word "special", as they are not related to general rules, each having an autonomous regulation. One possible explanation might be the fact that the authors of the NCC, building on earlier legislation, considered the contract as a source of obligations governed by Title II "Sources of obligations, Section I - the Contract" (Article 1166 et seq.).

Title IX does not cover all contracts presented in the NCC. If we were to consider the criterion of the voluntary agreement between two or more individuals or legal persons for the conclusion of a contract, we cannot explain why, for example, donation (Article 985 et seq.) is regulated under the category of gifts, and not as a contract. The donation contract comprises all the characters of a civil law contract. It is true that, alongside the will, the donation is an act free of charge, i.e. a gift, but its features are those of a civil contract.

Therefore, we consider that the donation contract must be placed alongside the other contracts, i.e. in Title IX and not in Title III, Gifts - Chapter II which starts with Section I - The conclusion of the contract. Title IX contains 20 chapters, each covering one type of contract, including the partnership agreement (Chapter VII).

* We refer to some of the specificities; others will be discussed in a future study 


\section{The partnership agreement}

According to Article 1881 (1) NCC "Through a partnership agreement, two or more persons mutually agree to cooperate for the pursuit of an activity, as well as to contribute to it by monetary contributions, in-kind benefits or specific knowledge, with the purpose of sharing the benefits or of benefiting from the economy which could arise. (2) Each shareholder contributes to the losses in proportion to the shares in the distribution of the benefit if not otherwise decided by agreement..."

As such, a partnership agreement is a contract by which two or more natural or legal persons mutually undertake to contribute in money, in kind and in work in order to perform an activity.

Therefore, we want to point out that the contribution of the parties, even an unequal one, to the social capital of the company, is a specific obligation thereof in relation to the obligations of the parties to the other contracts covered by the NCC. In the absence of a contribution in kind, in money or in work, we cannot speak of a civil law company or a trading company.

The act based on which a company is incorporated is a profit-oriented, consideration-based, commutative, consensual contract (Article 1884 NCC) except for those situations in which the contribution consists of immovable property, the contract becoming authentic (Article 1883 (2)) or when the written form is a condition of validity. The partnership agreement is a contract with successive enforcement and concluded intuitu personae, in most cases.

\section{The "synallagmatic" nature of the partnership agreement}

According to Article $1881 \mathrm{NCC}$, the parties mutually undertake to cooperate in order to perform an activity. We can consider the fact that the partnership agreement has synallagmatic nature, as indicated by some authors in their specialised works (Angheni, 2005). As arguments, they state that as the contracting parties have mutual obligations and corresponding rights, the partnership agreement is a bilateral contract based on the interpretation of the rules contained in Article 1896 (2) NCC which provide that "any partner who makes a contribution in the form of property or another right in ram on a property shall be fully responsible for making the contribution just as a seller is responsible in relation to a purchaser, whilst any partner who makes a contribution in the form of use of property is responsible for making the contribution just a lessor in responsible in relation to a lessee". The argumentation ends in the sense that if the sale-purchase agreement and the lease agreement are bilateral contracts then also the partnership agreement has this status.

Does the reciprocity of the parties provided for in the legislation as to cooperate with a view to perform an activity has the same meaning as reciprocity of obligations in the synallagmatic contracts?

Civil legal acts, depending on the number of persons participating in their conclusion, are divided into multilateral, bilateral and unilateral acts. The contracts as the bilateral acts are classified in unilateral and bilateral (synallagmatic) contracts having as criterion whether or not parties' obligations are subject to reciprocity. For example, contracts such as: donation, commodate, unpaid mandate, free of charge deposit is one-sided contracts whereas they give rise to obligations on one of the parties.

Where, however, between the contracting parties arise mutual obligations, i.e. a right of one party with a corresponding obligation of the other party and vice versa, contracts become synallagmatic. In other words, the obligations are incumbent on both parties and are different for each contracting party. In this respect, contracts 
such as: sale-purchase agreement, exchange agreement, lease, rental, remunerated mandate are synallagmatic contracts.

Based on these examples, we are questioning whether a partnership agreement is a synallagmatic contract. Under the classification of civil law acts, based on the number of persons expressing willingness participating in their conclusion, the partnership agreement is part of the bilateral or multilateral acts, in the sense that its conclusion involves two or more persons. When we group contracts in unilateral and bilateral (synallagmatic) contracts, can we include the partnership agreement in one of these categories? Are there reciprocal obligations?

It has been pointed out in the legal literature (Hamangiu, Rosetti-Bălănescu, Băicoianu, 1929) that a partnership agreement is synallagmatic whereas each partner undertakes in relation with the other partners specific obligations, the purpose being the performance of an activity. It is stated, however, that this kind of contract can be distinguished from other bilateral contracts by the fact that the obligations of each partner correspond, in substance, to those of others, whereas a common aim unites them. It is emphasised that in other bilateral contracts, obligations are different because the aim pursued by each party is different.

Given these clarifications, Article 1171 NCC states that in the synallagmatic contract, the obligations arising from it is reciprocal and interdependent. Otherwise, the contract is unilateral even if it involves obligations on both parties.

Even the legal definition under Article 1881 NCC shows that in a partnership agreement the parties agree (affectio societatis) on its conclusion, serving an economic purpose, manifested by common interests. Given the partners' common goal, the right of one party does not have a corresponding obligation incumbent on the other contracting party (Cojocaru, 2002), (Stănciulescu, V. Nemeș, 2013). In these circumstances, the obligations arising from the partnership agreement are the same for all its members. As the obligations are not mutual, the parties to the partnership agreement are not called debtors and creditors, but shareholders and partners.

As it stems from the NCC, the contribution which represents the primary obligation for all the parties to the contract may consist of: contribution in the form of property, use of property or work, and their scope may be uneven.

Therefore, these obligations may take the form of an obligation to give or an obligation to do. In the case of the obligation to give, the legal status of property changes, as it will be jointly used, irrespective whether the contribution consists of transfer of property or use of property, the property passes to the company, irrespective of its nature. Of course that all contracting parties shall aim to acquire property gains, but the shared ownership is meant for shared interests, shared purpose, and differs from the incidental ownership like co-ownership.

Therefore the legal status of property is different from that of property in co-ownership, the property brought into the company having a specific purpose, namely to be used jointly. Unlike co-ownership, in the case of a company the property cannot be divided between the members until the expiry of the agreement or when it has been achieved the purpose for which it was concluded or when all members of the company agree to that. Even in case of withdrawal, exclusion or death of a partner, the respective partner or the heirs of the deceased cannot request the restitution of the contribution. The entitled persons will only receive the equivalent of the assets brought into the company and this is because the assets have a common utility and not individual use. 
Also in terms of the penalty, the partnership agreement differs from the synallagmatic (bilateral) contracts. In case of bilateral contracts, when a party fails to perform its obligation and claims performance of the obligations by the other party, the latter may oppose the exception of non-performance, whilst such penalty may not be imposed for non-performance of obligations in a partnership agreement. Furthermore, if the parties to a synallagmatic contract may request, in case of default, rescission thereof when the contract is under uno ictu enforcement or termination thereof, when the contract is under successive enforcement, in the case of a partnership agreement the penalty for default is specific in the sense that culpable non-fulfilment of the obligation by a party by the deadline set out in the agreement leads to the exclusion of that partner from the company or termination by dissolution of the company when the conditions are not met for the company to operate (Article 1930 NCC)

\section{Conclusion}

We consider that, given the specificities of this contract, it can be classified as a truly special contract compared with all the other contracts covered by the NCC. In the case of the partnership agreement, two or more parties bring something to be jointly used for the purpose of carrying out an activity, and they have the same rights and obligations, as well as a common purpose.

\section{References}

- C. Hamangiu, I. Rosetti-Bălănescu, Al. Băicoianu, Tratat de drept civil român, 1929, Restitutio, Bucharest, All Publishing House, 1997;

- Fr. Deak, Tratat de drept civil. Contracte speciale, Actami Publishing House, Bucharest, 1999;

- M. Mureşan, Contracte speciale, Cluj-Napoca, Cordial Lex Publishing House, 1999;

- A. Cojocaru, Contractul de societate civilă, Magazine Studii de Drept Românesc 3-4, 2002;

- A. Cojocaru, Contracte civile, Lumina Lex Publishing House, Bucharest, 2004;

- Camelia Toader, Drept civil. Contracte speciale. Ediţia a II-a, All Beck Publishing House, Bucharest, 2005;

- S. Angheni, Noul Cod civil. Studii și comentarii, Vol. III, Partea a II-a, Cartea a V-a (art. 1650 - art. 2490) Contracte speciale. Garanții, Universul Juridic Publishing House, Bucharest, 2005 (Coordinator Prof. univ.dr. Marilena Uliescu);

- New Civil Code (Law No.287/2009)

- L. Stănciulescu, V. Nemeș, Dreptul contractelor civile și comerciale în NCC, Hamangiu Publishing House, Bucharest, 2013. 